\title{
Winter Cereals as Double Crops in Corn Rotations on New York Dairy Farms
}

\author{
Quirine M. Ketterings ${ }^{1}$, Shona Ort ${ }^{1}$, Sheryl N. Swink ${ }^{1}$, Greg Godwin ${ }^{1}$, Thomas Kilcer ${ }^{1}$, Jeff Miller ${ }^{2}$ \\ \& William Verbeten ${ }^{3}$ \\ ${ }^{1}$ Department of Animal Science, Cornell University, Ithaca, NY, USA \\ ${ }^{2}$ Cornell Cooperative Extension, Oneida County, Oriskany, NY, USA \\ ${ }^{3}$ Cornell Cooperative Extension, Northwest New York Dairy, Livestock and Field Crops Team, Lockport, NY, \\ USA
}

Correspondence: Quirine M. Ketterings, Nutrient Management Spear Program, Department of Animal Science, 323 Morrison Hall, Cornell University, Ithaca NY 14853, USA. Tel: 1-607-255-3061. E-mail: qmk2@cornell.edu

Received: December 1, 2014 Accepted: December 23, 2014 Online Published: January 15, 2015

doi:10.5539/jas.v7n2p18 URL: http://dx.doi.org/10.5539/jas.v7n2p18

\begin{abstract}
Weather extremes in 2012 and 2013 impacted corn silage and hay yields for many dairies in the northeastern United States and prompted a growing interest in double cropping of winter cereals for harvest as high quality forage in the spring. Here we report on (1) forage yield ranges of cereal rye and triticale in corn-cereal rotations in New York in 2012-2014, and (2) survey results of 30 New York farm managers who grew winter cereals as double crops with corn silage in 2013. Yields averaged 3.62 and $4.88 \mathrm{Mg} \mathrm{ha}^{-1}$ for cereal rye and triticale, respectively. On average, the surveyed farmers planted $8 \%$ of their tillable acres to winter cereal with the intent to harvest as forage. Triticale was the most frequently seeded double crop (70\%). Most stands were established with a drill (57\%). Manure was applied to $37 \%$ of the fields. Fertilizer nitrogen (N) was applied at dormancy break by $79 \%$ of the farmers with a median application rate of $67 \mathrm{~kg} \mathrm{~N} \mathrm{ha}^{-1}$. The biggest challenge with the double-crop rotation, identified by the farmers, was timely seeding of the double crop in the fall given late corn silage harvest and early onset of frost in the Northeast. Despite challenges encountered and questions about the impact of harvest of the winter cereal on the main crop, $83 \%$ of the surveyed farmers planned to continue to grow double crops.
\end{abstract}

Keywords: corn rotations; cover crops; dairy; double crops; winter cereals

\section{Introduction}

Interest in seeding winter cereals after corn (Zea mays L.) silage harvest as cover crops has been growing over time, as farmers and farm advisors recognize the importance of fall and spring ground coverage for erosion control after corn silage harvest, the potential of overwintering cereals to retain end-of-season nitrogen $(\mathrm{N})$, the need for a growing crop to improve nutrient use efficiency of fall-applied manure, and the addition of carbon (C) to soils through roots and crop residue (Long et al., 2013a, 2013b). However, the yield shortage due to the 2012 drought and the extremely wet growing conditions of 2013 prompted a growing number of farmers to evaluate the potential of overwintering winter cereals as double crops in corn rotations, to be harvested as a forage in May, prior to planting of the next corn silage crop. The two species particularly suited for this use in the northeastern United States (US) are cereal rye (Secale cereal L.) and triticale (x Triticosecale Wittm.).

Faced with uncertainties in annual weather patterns and greater occurrence of weather extremes, many farmers and advisors ask questions about yield potentials of winter cereals for forage production in corn silage rotations, and about agronomic practices. Given a short growing season in the northeastern US, inclusion of winter cereals for forage production can cause a delay in corn planting and the need for a shorter season corn variety. However, Jemison et al. (2012) showed boot-stage and soft-dough stage harvests of double crop combinations to yield 20 and 33\% more total biomass than full season corn in Maine and Vermont, while studies on a western New York (NY) farm indicated a $27 \%$ yield increase (Long et al., 2013b). These study results are consistent with findings in Iowa in work by Heggenstaller et al. (2009) that showed a $25 \%$ increase in dry matter (DM) yield over full 
season corn for a double crop corn-triticale rotation.

Information on attainable yields and agronomic management of winter cereals as forage double crops in the northeastern US is limited to a small number of trials. Here we report on (1) the DM yield of nineteen cereal rye fields and 44 triticale fields on commercial farms distributed throughout NY and harvested in May 2012-2014, and (2) farmer motivation for, practices, and experiences with double cropping of winter cereals for forage.

\section{Method}

\subsection{Yield Assessments}

Winter cereal yield determinations were done over a period of three years. In May of 2012, one cereal rye and thirteen triticale fields were sampled on commercial farms. At each location, four $96 \times 20 \mathrm{~cm}$ frames, spaced at least $50 \mathrm{~m}$ apart, were placed $10 \mathrm{~cm}$ off the ground and the biomass above the $10 \mathrm{~cm}$ mark was harvested. The DM content was determined using a forced-air oven set at 54 degrees C. Fields were located in western and northern NY, two regions where double cropping was practiced in 2011. Fields were identified by the farmer and his/her crop consultant. Fall seeding took place on 21 Sept. for the cereal rye field and between 12 Sept. and 4 Oct. for the triticale fields. Harvest was done in 2012 on 18 May (cereal rye field) and either 4 May (seven triticale fields in western NY) or 18 May (six triticale fields in northern NY). Fields were established and managed by the farmers; the two week difference in harvest window is consistent with regional climate differences within NY. New York is characterized predominantly by USDA Plant Hardiness Zones 4 and 5 but ranges from Zones 3 to 6 (USDA, 2012).

In spring of 2013 and 2014, 49 field harvest assessments were added to the database (35 in 2013 and 14 in 2014). These fields were part of a statewide 5-rate $\mathrm{N}$ response project with $\mathrm{N}$ rate trials conducted in four replications in each field. Fields were located in northern, eastern, central, western and southern NY. In fall of 2012, seeding took place from 15 Sept. to 10 Oct. (seven cereal rye fields) and from 9 to 20 Oct. (28 triticale fields). The $\mathrm{N}$ rate trials were established at dormancy break in the spring. Harvest of the trials took place on 15 or 20 May 2013 for the cereal rye trials, and from 6 to 24 May for the triticale trials. In fall 2013, eleven cereal rye fields (seeded between 30 Aug. and 20 Oct.) and three triticale fields (seeded between 26 and 30 Sept.) were added. Trials were harvested in 2014 between 12 and 21 May for cereal rye, and on 19 or 22 May for triticale. In both years of the $\mathrm{N}$ rate study, decisions related to seeding rates, seeding method, and manure management, pest management, and seeding and harvest dates were made by the farmers who hosted the trials. At each trial location, the $\mathrm{N}$ rates were applied to 3 by $3 \mathrm{~m}$ plots that were established using a randomized complete block design. Nitrogen was applied at dormancy break at rates of $0,34,67,101$, or $134 \mathrm{~kg} \mathrm{~N} \mathrm{ha}^{-1}$. Yield in the plots was determined by harvesting the area within three $96 \times 20 \mathrm{~cm}$ frames per plot at a $10 \mathrm{~cm}$ cutting height. Harvest took place at flag leaf to early boot stage. Results of the $\mathrm{N}$ response trials will be documented elsewhere. Here we report on yields at the most economic rate of return to $\mathrm{N}$ as determined in the $\mathrm{N}$ rate trials.

\subsection{Farmer Surveys}

The 3-page farmer survey included six components: (1) farm size, acreage in double crops, and number of years of experience of the farmer with double cropping of over-wintering cereals in corn rotations; (2) motivation for adding winter cereals to the corn rotation; (3) agronomic practices; (4) challenges encountered with double cropping; (5) double crop plans for the future; and (6) need for further information. The survey was completed by 30 of $31 \mathrm{NY}$ farmers who participated in the on-farm assessment of yield and crop response to $\mathrm{N}$ in the spring of 2013, representing northern (seven farms), eastern (three farms), central (one farm), western (twelve farms), and southern (seven farms) NY. The survey was deemed exempt from Institutional Review Board for Human Participants (IRB) review by the Cornell Institutional Review Board.

\section{Results}

\subsection{Yield Averages and Ranges}

Cereal rye fields averaged $3.65 \mathrm{Mg} \mathrm{DM} \mathrm{ha}^{-1}$ across all three years (nineteen fields), with an average minimum yield of $2.22 \mathrm{Mg} \mathrm{DM} \mathrm{ha}^{-1}$ and maximum of $5.38 \mathrm{Mg} \mathrm{DM} \mathrm{ha}^{-1}$ (Table 1; Figure 1). Triticale yields averaged 4.88 $\mathrm{Mg} \mathrm{DM} \mathrm{ha}^{-1}$ (44 fields) with an average minimum yield of $2.37 \mathrm{Mg} \mathrm{DM}^{-1} \mathrm{and}^{-1}$ maximum of $10.44 \mathrm{Mg} \mathrm{DM} \mathrm{ha}{ }^{-1}$ (Table 1; Figure 1). The highest producing field was a triticale field that was harvested 18 May 2012 following three weeks with exceptionally good growing conditions. 
Table 1. Average yields of cereal rye and triticale seeded after corn silage harvest and harvested for forage in May in New York in 2012-2014

\begin{tabular}{|c|c|c|c|c|c|c|}
\hline \multirow{2}{*}{ Species } & & \multirow{2}{*}{$\begin{array}{l}\text { Number } \\
\text { of fields }\end{array}$} & \multicolumn{4}{|c|}{ Yield } \\
\hline & & & Average & Standard Deviation & Min & $\operatorname{Max}$ \\
\hline & & & \multicolumn{4}{|c|}{--- } \\
\hline \multirow[t]{4}{*}{ Cereal rye } & 2012 & 1 & 5.38 & - & 5.38 & 5.38 \\
\hline & 2013 & 7 & 3.65 & 1.23 & 2.24 & 5.35 \\
\hline & 2014 & 11 & 3.47 & 1.16 & 1.64 & 5.40 \\
\hline & All & 19 & 3.63 & 1.19 & 2.22 & 5.38 \\
\hline \multirow[t]{4}{*}{ Triticale } & 2012 & 13 & 5.13 & 2.51 & 1.95 & 10.44 \\
\hline & 2013 & 28 & 4.82 & 1.23 & 2.46 & 6.76 \\
\hline & 2014 & 3 & 4.35 & 1.01 & 3.34 & 5.35 \\
\hline & All & 44 & 4.88 & 1.68 & 2.37 & 7.75 \\
\hline
\end{tabular}

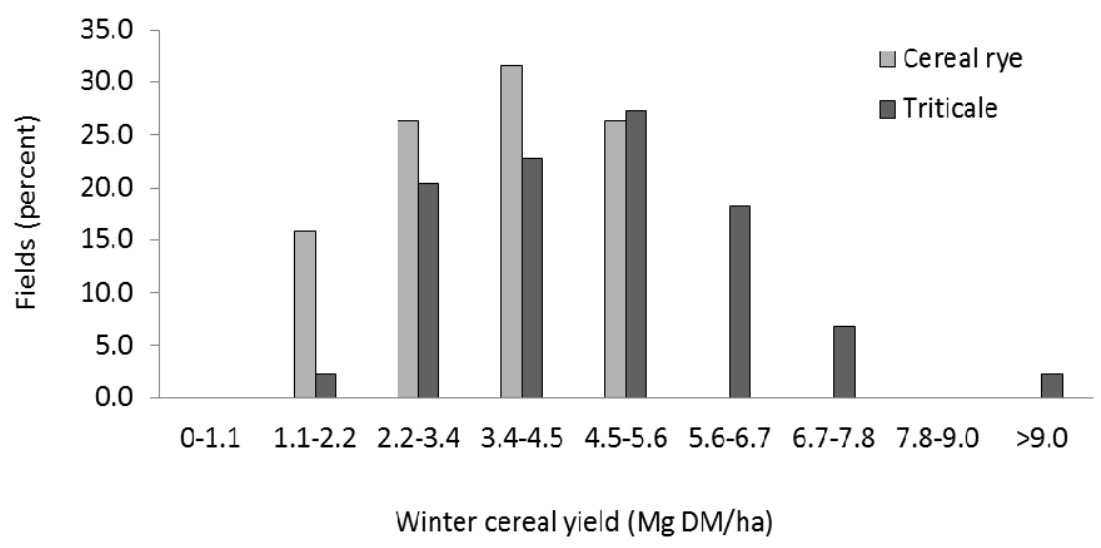

Figure 1. Distribution of yields of 19 cereal rye and 44 triticale fields harvested as forage in May of 2012-2014 in New York

No side-by-side comparisons were done between the two species so we cannot conclude if one species yielded higher than the other in any of the years. The results of the assessment show, however, that yields exceeding 2.24 $\mathrm{Mg} \mathrm{DM} \mathrm{ha}{ }^{-1}$ are common for both species (only two of nineteen cereal rye and one of 44 triticale fields yielded less than 1 ton DM/acre; Figure 1). Replicated side-by-side comparisons are needed to draw conclusions about species selection for optimal yield. Determining the factors that enable yields that exceed $6.5 \mathrm{Mg} \mathrm{DM} \mathrm{ha}{ }^{-1}$ on some fields (Figure 1) will be critical to increase farmer adoption of double cropping with small grain cereal crops.

\subsection{Farmer Survey}

\subsubsection{Area in Double Crops}

The 30 farmers who completed the survey managed from 55 to 2,430 ha of tillable cropland per farm $(19,855$ ha in total cropland), with $20 \%$ managing 203 ha or less versus $23 \%, 27 \%, 17 \%$ and $13 \%$ managing $203-405$, $405-810,810-1,215$, and more than 1,215 ha, respectively. For three farms, acres in double crops planted for forage harvest exceeded 203 ha (up to $284 \mathrm{ha}$ ). One farmer had terminated the stand as a cover crop while another harvested the winter cereal for grain. Forty percent of all farms seeded 20 ha or less versus $20 \%$ who seeded between 20 and 41 ha, $23 \%$ with 41-81 ha, and 10\% with 81-203 ha in double crops.

Of all farm tillable acres among the 30 farms, 1,526 ha $(8 \%)$ were double cropped with a winter cereal harvested as forage in May. The survey did not include questions related to percentage of tillable acres in corn silage but in $2012,468,000$ ha of cropland were planted to corn statewide of which $41 \%$ was harvested as silage and $59 \%$ as 
grain while hay was harvested on 631,800 ha (USDA-NASS, 2014). If, on average, the farms operated by the 30 surveyed farmers have a similar crop acreage distribution (43\% of the total acreage in corn of which $41 \%$ is harvested as silage), the $8 \%$ of all tillable acres in double crops represents approximately $45 \%$ of the acreage in corn silage on the cooperating farms in the study.

\subsubsection{Farmer Years of Experience}

For $14(47 \%)$ of the 30 farmers in the survey, 2013 was the first year of growing double crops on the farm. Nine farmers $(30 \%)$ had $2-4$ years of experience. Three farmers $(10 \%)$ had 5-7 years of experience while four farmers $(13 \%)$ had implemented double cropping for more than 10 years. These results are consistent with the relatively recent introduction of the corn-winter cereal for forage double crop rotation in NY. Seed sales of winter triticale seed have reflected this trend increasing from a total of 810-1,215 ha in 2010 to over 12,150 ha in 2013, and regional seed suppliers continue to increase seed supplies to keep up with this rapidly increasing demand from farmers for this double crop (Bill Verbeten, unpublished).

\subsubsection{Species Selection and Rotation}

Of all farmers in the survey, $25(83 \%)$ had tried triticale as a double crop versus fourteen farmers $(47 \%)$ who had experience with cereal rye. Winter wheat had been seeded by 6 farmers (20\%) (Table 2). Five farmers (17\%) indicated they had tried oats. Because oats winterkill and the fall growing season after corn silage harvest is short in the northeast, this crop is more commonly utilized as a winter-killed cover crop or as a forage double crop after winter wheat with fall harvest of the forage. Oats are also not considered suitable for $\mathrm{N}$ management of soils with a high leaching potential in NY (Ketterings et al., 2003) because when planted after corn silage oats can only capture a small amount of the manure N (Graham et al., 2012). It is therefore not surprising that only 17 $\%$ of the farmers had tried oats versus $83 \%$ and $46 \%$ for triticale and cereal rye, respectively. For most farms $(70 \%)$ triticale was the most frequently seeded double crop. Cereal rye was considered most frequently as well by $37 \%$ of the farmers (Table 2). Sixteen farmers (53\%) had never tried winter wheat. These results are consistent with the distribution of fields that were sampled to determine achievable forage yields as part of the $\mathrm{N}$ rate study in $2012-2013$, where $70 \%$ of the fields had been seeded to triticale versus $30 \%$ to cereal rye (Table 1 ).

Table 2. Species of winter cereal double crops grown for forage (A) and main crop planted after harvest of double crops for forage (B), ranked in order of frequency by 30 farmers who participated in double crop trials in 2012-2013. Several of the 30 farmers surveyed gave more than one reason for growing double crops. Oats, a non-overwintering cereal, was the only crop listed for the "Other" category. Some farms gave equal ranking to two forage species

\begin{tabular}{|c|c|c|c|c|c|c|c|c|c|c|c|}
\hline \multicolumn{3}{|l|}{$\overline{(\mathrm{A})}$} & \multicolumn{9}{|c|}{ Frequency of double crops selected to grown for forage } \\
\hline \multirow[b]{2}{*}{ Winter forage } & \multirow[b]{2}{*}{ Farms } & \multirow[b]{2}{*}{$\%$} & \multicolumn{2}{|c|}{----Most frequent--- } & \multicolumn{2}{|c|}{-----------2 nd ---------} & \multicolumn{3}{|c|}{-----------3 $3^{\text {rd }}---------$} & \multicolumn{2}{|c|}{---------Never------- } \\
\hline & & & Farms & $\%$ & Farms & $\%$ & Farms & $\%$ & & Farms & $\%$ \\
\hline Cereal rye & 14 & 47 & 11 & 37 & 2 & 7 & 1 & 3 & & 11 & 37 \\
\hline Triticale & 25 & 83 & 21 & 70 & 3 & 10 & 1 & 3 & & 2 & 7 \\
\hline Winter wheat & 6 & 20 & 1 & 3 & 5 & 17 & 0 & 0 & & 16 & 53 \\
\hline Other (oats) & 5 & 17 & 0 & 0 & 5 & 17 & 0 & 0 & & 9 & 30 \\
\hline \multirow[t]{2}{*}{ (B) } & & & \multicolumn{9}{|c|}{ Frequency of main crop planted after harvest of double crops for forage } \\
\hline & & & \multicolumn{3}{|c|}{--------Most frequent-------- } & \multicolumn{3}{|c|}{ 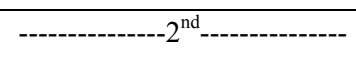 } & \multicolumn{3}{|c|}{ 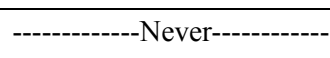 } \\
\hline Main crop & Farms & $\%$ & Farms & $\%$ & & Farms & $\%$ & & Farms & & 0 \\
\hline Corn silage & 24 & 80 & 23 & 77 & & 1 & 3 & & 1 & & \\
\hline Small grains & 4 & 13 & 1 & 3 & & 2 & 7 & & 12 & & 40 \\
\hline Vegetables & 4 & 13 & 3 & 10 & & 1 & 3 & & 14 & & 47 \\
\hline Alfalfa/grass & 3 & 10 & 1 & 3 & & 2 & 7 & & 14 & & 47 \\
\hline Soybeans & 2 & 7 & 2 & 7 & & - & - & & - & & \\
\hline
\end{tabular}

Most $(80 \%)$ of the fields, that were double cropped and harvested for forage in May on the 30 farms represented in the survey, were subsequently planted to corn. Thirteen percent seeded fields to small grains or vegetables (Table 2). These results reflect our focus on use of double crops in corn silage rotations for dairy farms. 


\subsubsection{Agronomic Practices}

The 35 on-farm $\mathrm{N}$ rate trials in 2013 included seven cereal rye and 28 triticale trials. Seeding rates ranged from 67 to $207 \mathrm{~kg}$ seed ha ${ }^{-1}$ for triticale and from 67 to $168 \mathrm{~kg} \mathrm{seed} \mathrm{ha}^{-1}$ for cereal rye. In total, 20 fields (57\%) were drilled versus fifteen (43\%) that were broadcast-seeded. Thirteen fields $(37 \%)$ received liquid dairy manure, either at the time of double crop establishment (12 fields; 34\%) or in Feb (1 field; 3\%) with application rates ranging from $23.3 \mathrm{~kL}$ to $112.2 \mathrm{~kL} \mathrm{ha}^{-1}$. All fields were seeded in either the last three weeks of Sept. (22 fields) or the first three weeks of Oct. (13 fields). Harvest took place between 6 and 29 May, 2013.

Of the 29 farmers who responded to the question about fertilizer use, 23 farmers (79\%) applied $\mathrm{N}$ fertilizer at dormancy break. Most common fertilizers were urea or urea mixed with ammonium sulfate ( $48 \%$ of the farmers). Ten farmers (34\%) used liquid urea ammonium nitrate with or without ammonium thiosulfate while the remaining farmers did not identify the source of $\mathrm{N}$ they used. Nitrogen application rates varied from zero (21\% of all farmers) to $45-56 \mathrm{~kg} \mathrm{~N}^{-1}(21 \%), 56-78 \mathrm{~kg} \mathrm{~N} \mathrm{ha}^{-1}(29 \%), 78-90 \mathrm{~kg} \mathrm{~N} \mathrm{ha}^{-1}(18 \%)$, and 90-118 $\mathrm{kg} \mathrm{N} \mathrm{ha}^{-1}$ (11\%). The average application rate for those farmers who applied $\mathrm{N}$ was $74 \mathrm{~kg} \mathrm{~N}^{-1}$ with a median of $67 \mathrm{~kg} \mathrm{~N}$ $\mathrm{ha}^{-1}$. The wide range in $\mathrm{N}$ application rates might reflect, among other things, the lack of knowledge about and guidance for $\mathrm{N}$ management for these winter cereals grown as forage crop in corn rotations.

Herbicide was applied to the double crops grown as forage in 2013 by only three of the 29 farmers $(10 \%)$ who responded to this question. None of the farmers indicated use of fungicides or insecticides for the winter cereals. This is not surprising as harvest takes place prior to the onset of common diseases and pests for winter cereals in the Northeast.

\subsubsection{Farmer Motivation for Double Crop}

Sixteen farmers $(53 \%)$ listed the desire to increase the forage production on a limited crop area as the main reason for seeding winter cereals (Table 3). Ten (33\%) indicated they had seeded double crops primarily to address a feed shortage (emergency feed). Increased farm profits and higher quality feed were listed as reasons for including double crops by five (17\%) and four (13\%) of the farmers, respectively. Following the experiences of the 2013 growing season, a larger number of farmers identified the desire to increase forage production on a limited acreage (a shift from 53\% in fall of 2012 to $63 \%$ after the 2013 growing season) while emergency forage needs declined as a prime reason for double cropping from 33\% in 2012 to $10 \%$ after the 2013 growing season. Of all farmers, $25(83 \%)$ planned to continue to grow winter cereals as a forage crop in the future with an additional five farmers $(17 \%)$ who said they might consider it. In total, sixteen farmers $(53 \%)$ planned to increase the acreage planted to double crops in the coming year while another seven (23\%) said they may do so but were not sure yet.

Table 3. Main reason for growing double crops as forage in 2013 and primary reason for continuing to grow double crops as forage in the future. Several of 30 farmers surveyed gave more than one reason for growing double crops

\begin{tabular}{|c|c|c|c|c|c|}
\hline \multirow{2}{*}{\multicolumn{2}{|c|}{ Main reason for growing double crop for harvest as forage: }} & \multicolumn{2}{|c|}{------In 2013------ } & \multicolumn{2}{|c|}{------ Future ------ } \\
\hline & & Farms & $\%$ & Farms & $\%$ \\
\hline \multicolumn{2}{|c|}{ Increase forage productivity on limited acreage } & 16 & 53 & 19 & 63 \\
\hline \multicolumn{2}{|c|}{ Emergency forage/feed if the need presented itself } & 10 & 33 & 3 & 10 \\
\hline \multicolumn{2}{|c|}{ Increase farm profits ( small grain or vegetable rotation) } & 5 & 17 & 5 & 17 \\
\hline \multicolumn{2}{|c|}{ Higher quality forage to feed a certain group(s) of animals } & 4 & 13 & 5 & 17 \\
\hline \multicolumn{6}{|c|}{ Other reasons (in 2013): $\quad$ (in the future): } \\
\hline "Profitable cover crop" & "Profitable cover crop" & 3 & 10 & 2 & 7 \\
\hline "Soil quality"/“Soil health" & "Build organic matter"/“Soil health" & 2 & 7 & 3 & 10 \\
\hline \multirow[t]{2}{*}{ "Need straw for mulch"x } & "Add cows without increasing land" & 1 & 3 & 1 & 3 \\
\hline & "BMP, CAFO requirements"y & & & 2 & 7 \\
\hline
\end{tabular}

Note. ${ }^{\mathrm{x}}$ This farm planted the double crop for forage, but harvested it for grain and straw; ${ }^{\mathrm{y}} \mathrm{BMP}=\mathrm{best}$ management practice; $\mathrm{CAFO}=$ concentrated animal feeding operation. 


\subsubsection{Challenges and Information Needs}

The biggest challenge with the double crop rotation identified by the farmers was getting a double crop seeded in time in the fall (Table 4), consistent with the short period between corn silage harvest and onset of cold weather. In addition, nine farmers (32\%) pointed to the potential for delay in corn planting following double crop harvest. Five farmers $(18 \%)$ identified labor and time involved as a constraint while four farmers (14\%) pointed to weather challenges during harvest time of the double crops (too wet in spring to get equipment on fields).

Table 4. Greatest challenges with growing winter cereals as double crops for forage according to 30 survey participants with experience in growing double crops. Several respondents described more than one challenge

\begin{tabular}{lll}
\hline Greatest challenge & Farms & $\%$ \\
\hline Fall planting timing, getting corn off in time to plant double crop & 14 & 50 \\
Harvest timing of double crop forage to allow for planting of next crop & 9 & 32 \\
Available labor and time & 5 & 18 \\
Weather issues at harvest (too wet) & 4 & 14 \\
Low tonnage, possible need for N stabilizer & 1 & 3 \\
Production costs per ton & 1 & 3 \\
Loss of seed to geese feeding in fall & 1 & 3 \\
\hline
\end{tabular}

Many farmers identified the impact of the double crop on the following crop as the most important aspect of double cropping that they needed to learn more about (Figure 2). Respondents to the survey wanted to know more about the impact of nutrient uptake and removal by the double crop harvest on fertilizer needs of the crop seeded after double crop harvest. This was followed by questions about economics and forage quality (milk production potential of the winter cereals), and harvest methods.

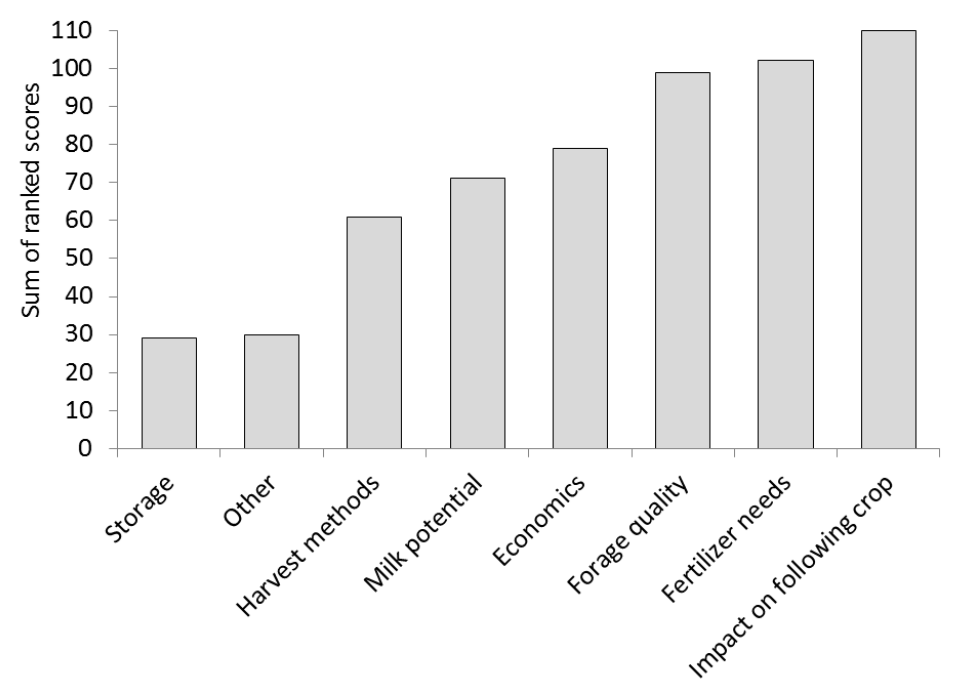

Figure 2. Collective summary of ranking by survey participants of aspects of double crops for forage use that would benefit from more information to aid in decision-making regarding its role in the farm's cropping system.

Farmers ranked eight aspects in order of importance: most important (1) to least important (8). To calculate a score, values were assigned in reverse order to the ranking ( 8 for most important, 1 for least important, 0 if not ranked) and multiplied by the number of responses for each ranking of the particular aspect. The scores for each ranking of an aspect were then added together to obtain the comparative value presented in the bar graph

Other questions raised by farmers related to seeding methods and rates, manure use to supply $\mathrm{N}$ needs, fertilizer 
$\mathrm{N}$ management for high leaching soils, and tradeoffs with shorter season corn varieties. In addition, farmers asked questions about variety selection, integrated pest management and diseases, and on-farm seed collection. Some farmers wanted more information on seeding rate as related to planting date and benefits of using a drill versus broadcasting of the double crop seed. Others raised questions about the costs per acre to plant and harvest the double crop and potential yield trade-offs with a delay in corn planting due to inclusion of the winter cereal, wondering about minimum yields needed to cover the cost of production of the double crop.

\section{Discussion and Implications}

Yield assessment data showed that $71 \%$ of all fields in the study exceeded $3.36 \mathrm{Mg} \mathrm{ha}^{-1}$ with an average of 3.62 $\mathrm{Mg} \mathrm{ha}^{-1}$ for cereal rye and $4.88 \mathrm{Mg} \mathrm{ha}^{-1}$ for triticale (Figure 1). In comparison, the average corn silage yield in 2012 in NY amounted to $13.33 \mathrm{Mg} \mathrm{ha}^{-1}$ (USDA-NASS, 2014). If we assume no corn yield loss upon shifting to a shorter growing season (later planting), these yield data suggest the potential for a per acre yield increase of $27 \%$ for corn and cereal rye rotations versus a 37\% yield increase for corn and triticale rotations, consistent with findings of Heggenstaller et al. (2009), Jemison et al. (2012), and Long et al. (2013b). However, a shorter season corn variety might need to be selected as most double crop harvests took place between May 5 and 25, delaying corn planting by one or two weeks. Variety trials conducted in 2012 in NY (Cox et al., 2012) showed $0.56 \mathrm{Mg}$ ha ${ }^{-1}$ lower yields for every 5 day decrease in corn relative maturity. Cox et al. (2013) showed a yield difference between 95-100 d and 106-110 d corn varieties at two NY locations, averaged across all hybrids in the NY assessment, of $2.47 \mathrm{Mg} \mathrm{DM} \mathrm{ha}^{-1}$, while 84-90 d corn varieties averaged 0.86 Mg DM ha ${ }^{-1}$ less than 101-106 d corn varieties in the colder regions of the state. However, in both years a large number of short-day corn varieties had equal or higher yields than many of their longer-day counterparts (Cox et al., 2012, 2013). These data suggest an overall (season) yield increase can be obtained with the inclusion of the double crop in corn silage rotations in the northeastern US, even if a shorter day variety is selected. However, economic analyses need to be conducted to evaluate what yield level is needed for a positive economic return on investment.

\section{Conclusions}

Our study suggests that, despite the often short fall season, NY farmers can successfully implement corn-winter cereal double cropping practices and have done so on an estimated $45 \%$ of their corn silage acres, averaging yields of $3.62 \mathrm{Mg} \mathrm{ha}^{-1}$ for cereal rye and $4.88 \mathrm{Mg} \mathrm{ha}^{-1}$ for triticale. Double cropping with winter cereals can benefit agriculture environmental management and increase per ha forage production.

\section{Acknowledgements}

This work was funded through grants from the Northern New York Agricultural Development Program (NNYADP), Federal Formula Funds, USDA-NRCS (Conservation Innovation Grant for the Upper Susquehanna Watershed), and Northeast Region Sustainable Agriculture Research and Education (NESARE). We thank the many farmers who participated in the project as well as our collaborators Paul Cerosaletti, Janice Degni, Dale Dewing, Kevin Ganoe, Mike Hunter, Kitty O’Neil, Ashley Pierce (Cornell Cooperative Extension); Jonathan Barter, Steve Loraine, and Aaron Ristow (Soil and Water Conservation Districts); Shawnna Clark, Martin van der Grinten, and Paul Salon (USDA-NRCS Big Flats Plant Materials Center); Joe Lawrence (Lowville Farmers Co-op); Shawn Bossard (Morrisville State College), and agricultural consultants Peter Barney (Barney Agricultural Consulting), Eric Beaver and Mike Contessa (Champlain Valley Agronomics), Jeff Willard and Jeremy Langer (Agricultural Consulting Service).

\section{References}

Cox, W. J., Cherney, J., Atkins, P., \& Paddock, K. (2012). New York corn silage hybrid tests - 2012. Department of Crop and Soil Sciences Extension Series E12-1. Cornell University, Ithaca NY. Retrieved November 30, 2014, from http://www.fieldcrops.org/VarietyTrials/Documents/2012\%20Corn\%20Silage\%20Report.pdf

Cox, W. J., Cherney, J., Atkins, P., \& Paddock, K. (2013). New York corn silage hybrid tests - 2013. Department of Crop and Soil Sciences Extension Series No. E13-1. Cornell University, Ithaca NY. Retrieved December 17, 2014 from http://fieldcrops.org/VarietyTrials/Documents/2013\%20Corn\%20Silage\%20Report.pdf

Graham, C., Van Es, H., \& Schindelbeck, B. (2012). Rye vs. oat: Environmental benefits vary greatly. What's Cropping Up? 22(4), 3-4.

Heggenstaller, A. H., Liebmann, M., \& Anex, R. P. (2009). Growth analysis of biomass production in sole-crop $\begin{array}{lllll}\text { and double-crop corn } & \text { Systems. }\end{array}$ http://dx.doi.org/10.2135/cropsci2008/12/0709

Jemison, J. M., Darby, H. M., \& Reberg-Horton, S. C. (2012). Winter grain-short season corn double crop forage 
production for New England. Agronomy Journal, 104, 256-264. http://dx.doi.org/10.2134/agronj2011.0275

Ketterings, Q. M., Klausner, S. D., \& Czymmek, K. J. (2003). Nitrogen guidelines for field crops in New York. Second Release. Department of Crop and Soil Sciences Extension Series E03-16. Cornell University, Ithaca, NY. Retrieved November 30, 2014, from http://nmsp.cals.cornell.edu/publications/extension/Ndoc2003.pdf

Long, E., Ketterings, Q. M., \& Czymmek, K. J. (2013a). Survey of cover crop use on New York dairy farms. Crop Management. http://dx.doi.org/10.1094/CM-2013-0019-RS.

Long, E., Van Slyke, K., Ketterings, Q. M., Godwin, G., \& Czymmek, K. (2013b). Triticale as a cover and double crop on a New York dairy. What's Cropping Up? 23(1), 3-5. Retrieved November 30, 2014, from http://css.cals.cornell.edu/sites/css.cals.cornell.edu/files/shared/documents/wcu/WCUvol23no1.pdf

USDA. (2012). USDA Plant Hardiness Zone Map, 2012. Agricultural Research Service, United States Department of Agriculture. Retrieved November 30, 2014, from http://planthardiness.ars.usda.gov

USDA-NASS. (2014). New York State Agricultural Statistics Service; County Estimates. Retrieved November 30, 2014, from http://www.nass.usda.gov/Statistics_by_State/New_York/Publications/County_Estimates/in dex.asp

\section{Copyrights}

Copyright for this article is retained by the author(s), with first publication rights granted to the journal.

This is an open-access article distributed under the terms and conditions of the Creative Commons Attribution license (http://creativecommons.org/licenses/by/3.0/). 